\title{
Pengaruh Profitabilitas dan Leverage pada Nilai Perusahaan dengan Corporate Social Responsibility Sebagai Variabel Pemoderasi
}

\author{
Ni Made Laksmi Dewi ${ }^{1}$ \\ I D.G. Dharma Suputra ${ }^{2}$ \\ ${ }^{1,2}$ Fakultas Ekonomi dan Bisnis Universitas Udayana (Unud), Bali, Indonesia \\ e-mail: laksmidewiarjana@yahoo.com
}

\begin{abstract}
ABSTRAK
Tujuan penelitian ini adalah untuk mengetahui dan mendapatkan bukti empiris mengenai pengaruh profitabilitas dan leverage pada nilai perusahaan dengan Corporate Social Responsibility sebagai variabel pemoderasi.Penelitian ini dilakukan pada perusahaan pertambangan yang terdaftar di BEI tahun 2015-2017.Jumlah sampel yang diambil sebanyak 14 perusahaan dengan jumlah amatan penelitian sebanyak 42 sampel dalam 3 tahun, melalui metode nonprobability dengan teknik purposive sampling.Teknik analisis penelitian ini menggunakan Moderate Regression Analysis (MRA).Berdasarkan hasil analisis ditemukan bahwa profitabilitas berpengaruh positif signifikan pada nilai perusahaan.Leverage berpengaruh negatif tidak signifikan pada nilai perusahaan. Corporate Social Responsibilitymemperkuat pengaruh profitabilitas pada nilai perusahaan.Corporate Social Responsibilitymemperlemah pengaruh leverage pada nilai perusahaan.

Kata kunci: Profitabilitas, leverage, corporate social responsibility, nilai perusahaan.
\end{abstract}

\begin{abstract}
The purpose of this study was to find out and obtain empirical evidence about the effect of profitability and leverage on firm value with Corporate Social Responsibility as a moderating variable. This study was conducted at mining companies listed on the Stock Exchange in 2015-2017. The number of samples taken was 14 companies with a number of research observations were 42 samples in 3 years, through nonprobability methods with purposive sampling technique. The analysis technique of this study used the Moderate Regression Analysis (MRA). Based on the results of the analysis it was found that profitability had a significant positive effect on firm value. Leverage had no significant negative effect on firm value. Corporate Social Responsibility strengthens the influence of profitability on corporate value. Corporate Social Responsibility weakens the influence of leverage on firm value.

Keywords: Profitability, leverage, corporate social responsibility, corporate value.
\end{abstract}

\section{PENDAHULUAN}

Nilai perusahaan diartikan sebagai persepsi investor terhadap tingkat kenaikan perusahaan yang sering dikaitkan dengan harga saham. Semakin tinggi harga saham semakin tinggi nilai perusahaan, sebaliknya semakin rendah nilai perusahaan harga saham juga rendah. Nilai perusahaan atau value of the firm adalah konsep penting bagi investor karena merupakan indikator bagaimana pasar 
Ni Made Laksmi Dewi dan I D.G. Dharma Suputra. Pengaruh ...

menilai perusahaan secara keseluruhan (Wongso, 2012). Nilai perusahaan dapat mencerminkan nilai aset yang dimiliki oleh perusahaan. Pada perusahaan go public, nilai perusahaan dapat direfleksikan melalui harga pasar saham. Haruman (2008) menyatakan nilai perusahaan yang tinggi dapat meningkatkan kemakmuran bagi para pemegang saham, sehingga para pemegang saham akan menginvestasikan modalnya. Berikut nilai perusahaan pertambangan yang terdaftar di Bursa Efek Indonesia tahun 2015-2017 ditunjukkan oleh Gambar 1 sebagai berikut :

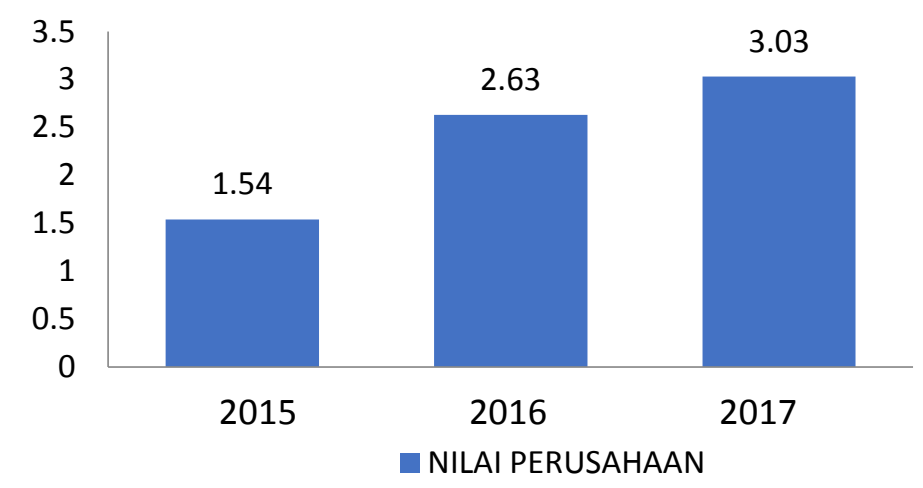

Gambar 1. Grafik Nilai Perusahaan Sektor Pertambangan di BEI Tahun 2015-2017

Sumber : Data diolah, 2018

Gambar 1 menunjukkan bahwa tahun 2016 nilai perusahaan mengalami peningkatan sebesar 1,09 dari tahun 2015 sebesar 1,54 menjadi 2,63 di tahun 2016. Sementara pada tahun 2017 kembali meningkat sebesar 0,40 dari tahun 2016 sebesar 2,63 menjadi 3,03 di tahun 2017.

Berdasarkan fenomena tersebut terdapat beberapa faktor yang mempengaruhi nilai perusahaan, yaitu profitabilitas dan leverage (kebijakan hutang). Salah satu faktor yang mempengaruhi nilai perusahaan adalah besar kecilnya profitabilitas yang dihasilkan perusahaan itu sendiri. Profitabilitas adalah 
kemampuan suatu perusahaan untuk menghasilkan laba selama periode tertentu. Laba merupakan elemen dalam menciptakan nilai perusahaan karena penilaian prestasi perusahaan dapat dilihat dari kemampuan perusahaan menghasilkan laba jika kemampuan perusahaan tersebut dalam menghasilkan laba meningkat maka harga saham juga akan meningkat. Profitabilitas memiliki peran penting dalam perusahaan karena semakin baik pertumbuhan profitabilitas berarti prospek perusahaan di masa depan juga baik artinya nilai perusahaan juga akan dinilai baik dimata investor dan akan meningkatkan daya tarik perusahaan. Menurut Agustina (2012) para investor menanamkan saham pada perusahaan untuk mendapatkan return yang terdiri dari yield dan capital gain. Return on Asset (ROA) adalah rasio yang mengukur kemampuan dari modal yang diinvestasikan dalam keseluruhan aktiva untuk menghasilkan neto. Nilai ROA yang tinggi diartikan sebagai sinyal positif bagi investor untuk memprediksikan bahwa perusahaan di masa depan dalam kondisi yang menguntungkan.

Selain profitabilitas nilai perusahaan juga di pengaruhi oleh leverage. Leverage menunjukkan kemampuan perusahaan membayar seluruh kewajiban finansial (jangka pendek dan jangka panjang), atau mengukur sejauh mana perusahaan dibiayai dengan hutang (Wiagustini, 2010:76). Dalam menentukan leverage, perusahaan harus mempertimbangkan dengan lebih baik terlebih dahulu karena dapat menimbulkan beban dan juga resiko bagi perusahaan apabila perusahaan tersebut dalam kondisi yang buruk karena penggunaan hutang ini akan berdampak terhadap nilai perusahaan. Menurut Mardiyati (2012) peningkatan pada leverage dapat memberikan dua macam sinyal, yaitu berita baik (goodnews) 
Ni Made Laksmi Dewi dan I D.G. Dharma Suputra. Pengaruh ...

dan berita buruk (badnews) artinya leverage menunjukkan berita baik jika peningkatan tersebut merefleksikan kemampuan manajemen untuk meningkatkan nilai perusahaan. Sebaliknya peningkatan leverage menunjukkan berita buruk (badnews) apabila manajer melakukan karena terpaksa dan bukan karena alasan efisiensi.

Penelitian mengenai profitabilitas, leverage, nilai perusahaan danCorporate Social Responsibility telah di teliti oleh beberapa peneliti sebelumnya. Pramana dan Mustanda (2016) menyatakan bahwa profitabilitas berpengaruh positif terhadap nilai perusahaan.Sedangkan menurut Nila dan Suryanawa (2018) profitabilitas berpengaruh positif tidak signifikan terhadap nilai perusahaan. Hasil lain ditunjukkan oleh Wulandari dan Wiksuana (2017) menyatakan bahwa profitabilitas berpengaruh negatif dan tidak signifikan terhadap nilai perusahaan. Jayanti dan Suputra (2015) dan Raharja dan Dwiana (2016) menyatakan leverage berpengaruh negatif terhadap nilai perusahaan. Sedangkan Wulandari dan Wiksuana (2017) menyatakan leverage berpengaruh positif terhadap nilai perusahaan, Rizqia (2013) menemukan bahwa leverageberpengaruh positif dan signifikan terhadap nilai perusahaan.

Berdasarkan hasil yang belum konsisten yang ditemukan dalam penelitianpenelitian sebelumnya mengenai profitabilitas dan leverage pada nilai perusahaan, maka peneliti memutuskan untuk meneliti kembali karena penting untuk mengetahui faktor apa saja yang dapat mempengaruhi nilai perusahaan maka peneliti menambah satu variabel moderasi yaitu Corporate Social Responsibility (CSR). Corporate Social Responsibility (CSR) dijadikan sebagai variabel 
moderasi karena diduga berperan dalam memoderasi hubungan profitabilitas dan leverage terhadap nilai perusahaan secara langsung.

Tanggung jawab sosial atau Corporate Social Responsibility (CSR) merupakan bentuk tanggung jawab perusahaan dalam memperbaiki kerusakan lingkungan dan kesenjangan sosial yang diakibatkan oleh aktivitas operasional perusahaan. Corporate Social Responsibility (CSR) merupakan faktor lain yang dipertimbangkan perusahaan dalam meningkatkan nilai perusahaan karena perusahaan telah menyadari arti penting menerapkan program $C S R$ merupakan bagian dari stategi bisnis yang strategis dan dianggap mampu menaikkan citra perusahaan. Semakin banyak bentuk tanggung jawab sosial perusahaan terhadap lingkungan maka citra perusahaan akan meningkat sehingga investor lebih berminat pada perusahaan yang memiliki citra yang baik di masyarakat. Menurut Georgeta dan Florinita (2013) CSR merupakan komitmen berkelanjutan dari bisnis untuk berperilaku etis dan berkontribusi terhadap pembangunan ekonomi sekaligus untuk meningkatkan kualitas angkatan kerja dan masyarakat setempat secara luas. Pengungkapan tanggung jawab sosial mencerminkan kualitas perusahaan tersebut dan diharapkan dapat memengaruhi keputusan investor dalam pengambilan keputusan investasi. Peraturan terkait dengan $C S R$ dimuat dalam Undang-Undang No.40 Tahun 2007 tentang Perseroan Terbatas dan Peraturan Pemerintah Republik Indonesia No 47 Tahun 2012 yang menyatakan bahwa perusahaan yang memanfaatkan atau berdampak terhadap fungsi sumber daya alam dituntut tidak hanya mencari keuntungan semata, akan tetapi juga dituntut 
Ni Made Laksmi Dewi dan I D.G. Dharma Suputra. Pengaruh ...

untuk memperhatikan masyarakat luas dengan melakukan tanggung jawab sosial dan lingkungan (Pramana, 2016).

Hal ini dapat dijelaskan dalam teori legitimasi yangmenyatakan bahwa pengungkapan tanggung jawab sosial perusahaan dilakukan untuk mendapatkan nilai positif dan legitimasi dari masyarakat. Para investor akan tertarik berinvestasi pada perusahaan tersebut dan akan berpengaruh pada peningkatan nilai perusahaan.

Perusahaan pertambangan dipilih sebagai objek penelitian karena perusahaan pertambangan kegiatan operasinya berkaitan dengan kegiatan eksploitasi sumber daya alam yang renta menimbulkan kerusakan lingkungan sekitar wilayah lingkungan pertambangan, sebagai contohnya adalah pencemaran lingkungan di Teluk Buyat karena aktivitas pertambangan oleh PT Newmont Minahasa Raya (PT NMR). Teluk Buyat dijadikan sebagai lokasi pembuangan limbah tailing tambang PT NMR yang mengakibatkan ekosistem perairan laut di Teluk Buyat rusak parah akibat buangan tailingsetiap harinya (Dinda, dkk, 2013). Kegiatan-kegiatan yang dilakukan perusahaan pertambangan banyak menimbulkan masalah sosial sehingga perusahaan pertambangan banyak menyajikan informasi pengungkapan $C S R$ dan besaran biaya yang dikeluarkan, khususnya yang berhubungan dengan ketenaga kerjaan, komunitas sosial dan kerusakan lingkungan.

Perusahaan pertambanganberpotensi dalam merusak lingkungan sekitar wilayah pertambangan, dengan melakukan tanggung jawab sosial perusahaan akanmemberikan citra yang baik bagi perusahaan dan menjadi daya tarik bagi 
investor sehingga dapat meningkatkan nilai perusahaan. Pengungkapan tanggung jawab sosial pada perusahaan pertambangan selanjutnya dapat memperkuat pengaruh dari pengungkapan laporan yang bersifat akuntansi khususnya profitabilitas dan leverage terhadap nilai perusahaan (Chen dan Chen, 2011).

Kasmir (2012) menyatakan bahwa profitabilitas merupakan rasio untuk menilai kemampuan perusahaan dalam mencari keuntungan. Setiap perusahaan berusaha untuk meningkatkan profitabilitas perusahaannya karena dengan memperoleh keuntungan yang besar akan berpengaruh pada kemampuan perusahaan untuk membayar dividen yang akan berdampak pada peningkatan nilai perusahaan. Profitabilitas yang tinggi mencerminkan kemampuan perusahaan dalam menghasilkan keuntungan yang tinggi bagi para pemegang saham. Dengan rasio profitabilitas yang tinggi akan menarik minat para investor untuk menanamkan modalnya diperusahaan. Teori sinyal menjelaskan perusahaan yang memiliki nilai lebih akan menjadi sinyal positif bagi investor dan investor akan tertarik pada perusahaan yang memiliki prospek yang menjanjikan. Tingginya tingkat profitabilitas yang dihasilkan menunjukkan prospek perusahaan dalam menjalankan operasinya di masa depan juga meningkat sehingga nilai perusahaan yang tercermin dari harga saham perusahaan akan meningkat pula.

Penelitian yang dilakukan oleh Malino dan Wirawati (2017), Naceur dan Goaied (2002) menunjukkan hasil bahwa profitabilitas berpengaruh positif dan signifikan. Penelitian yang dilakukan oleh Kurniasari dan Warastuti (2015) juga menunjukan hasil bahwa profitabilitas berpengaruh pofitif dan signifikan terhadap nilai perusahaan. Dewi dan Mertha (2018) juga meneliti tentang pengaruh 
Ni Made Laksmi Dewi dan I D.G. Dharma Suputra. Pengaruh ...

profitabilitas terhadap nilai perusahaan dimana hasilnya ditemukan bahwa profitabilitas berpengaruh positif signifikan terhadap nilai perusahaan. Sedangkan Wulandari dan Wiksuana (2017) menyatakan profitabilitas berpengaruh negatif dan tidak signifikan terhadap nilai perusahaan.Hipotesis yang diajukan dalam penelitian ini berdasarkan penelitian sebelumnya adalah sebagai berikut :

$\mathrm{H}_{1}$ : Profitabilitas berpengaruh positif terhadap nilai perusahaan.

Hutang merupakan salah satu sumber pembiayaan eksternal yang digunakan oleh perusahaan untuk membiayai kebutuhan dananya. Leverage atau kebijakan hutang digambarkan untuk melihat sejauh mana aset perusahaan dibiayai oleh hutang atau modal sendiri. Dalam pengambilan keputusan akan penggunaan hutang ini harus mempertimbangkan besarnya biaya tetap yang muncul dari hutang berupa bunga yang akan menyebabkan semakin meningkatnya leverage keuangan dan semakin tidak pastinya tingkat pengembalian bagi para pemegang saham biasa. Perusahaan akan cenderung untuk menjaga komposisi hutang mereka.

Semakin besar rasio leverage suatu perusahaan, maka perusahaan akan menahan laba operasional perusahaannya untuk digunakan melunasi hutang perusahaan. Teori sinyal menjelaskan bahwa perusahaan dengan kualitas baik akan dengan sengaja memberikan sinyal pada pasar, dengan demikian pasar diharapkan mampu membedakan perusahaan kualitas baik dan buruk jika dilihat dari jumlah hutang yang dikelola dan digunakan oleh perusahaan (Wulandari, 2017). Rasio leverage yang tinggi tentu akan mempengaruhi penilaian pemegang saham pada saat akan menanamkan modal mereka, mereka tidak akan 
menanamkan modal pada perusahaan yang tidak memiliki kemampuan untuk melunasi seluruh kewajibannya. Perusahaan juga akan kesulitan untuk memperoleh dana pinjaman dari pihak dari luar lagi (Bernandhi, 2013).

Cheng dan Tzeng (2011) menyatakan leverage memiliki hubungan yang positif dan signifikan terhadap nilai perusahaan. Wulandari dan Wiksuana (2017) juga meneliti mengenai pengaruh leverage terhadap nilai perusahaan, dimana dalam penelitian tersebut ditemukan bahwa leverage berpengaruh positif dan signifikan terhadap nilai perusahaan. Berbeda dengan Purnama dan Abundanti (2013) menemukan bahwa leverage berpengaruh negatif terhadap nilai perusahaan. Penelitian Jayanti dan Suputra (2015) dalam penelitiannya menemukan bahwa leverage berpengaruh negatif terhadap nilai perusahaan. Hipotesis yang diajukan dalam penelitian ini berdasarkan penelitian sebelumnya adalah sebagai berikut :

$\mathrm{H}_{2}$ :Leverage berpengaruh negatif pada nilai perusahaan.

Profitabilitas yaitu kemampuan perusahaan untuk memperoleh laba (Lu et al.,2010). Menurut Preston (1978) dalam Agustine (2014) menyatakan bahwa semakin tinggi tingkat profitabilitas suatu perusahaan maka pengungkapan informasi sosial yang dilakukan perusahaan akan semakin besar. Peningkatan suatu nilai perusahaan tidak selalu berasal dari tingkat profitabilitas yang tinggi karena apabila suatu perusahaan yang peduli terhadap lingkungan dianggap lebih memperhatikan kinerja perusahaan dimasa depan sehingga akan dipandang positif oleh investor. Teori legitimasi mendorong perusahaan untuk melakukan pengungkapan sukarela sebagai salah satu bentuk tanggungjawab terhadap 
Ni Made Laksmi Dewi dan I D.G. Dharma Suputra. Pengaruh ...

kontrak sosial yang dimiliki antara perusahaan dengan komunitas sekitar (Guthrie et al., 2004).

Tingkat profitabilitas yang semakin besar menunjukan perusahaan mampu mendapatkan laba yang semakin besar, sehingga perusahaan mampu untuk meningkatkan aktivitas tanggung jawab sosial, serta mengungkapkan tanggung jawab sosialnya dalam laporan tahunan dengan lebih luas dengan tujuan akhir meningkatkan nilai perusahaan (Nawaiseh et al, 2015). Semakin baik kinerja yang dilakukan perusahaan didalam memperbaiki lingkungannya (kinerja ekonomi, lingkungan dan sosial), maka pengaruh laba semakin kuat dalam meningkatkan nilai perusahaan sebagai akibat dari para investor yang menanamkan sahamnya pada perusahaan. Sehingga dapat disimpulkan bahwa, CSR akan memperkuat pengaruh laba dalam meningkatkan nilai dari perusahaan.

Qomariah (2015) dalam penelitiannya menemukan bahwa pengungkapan CSR mampu memperkuat pengaruh profitabilitas terhadap nilai perusahaan. Hasil penelitian tersebut diperkuat oleh penelitian yang dilakukan oleh Lin et al.,(2015) yang menunjukan pengungkapan $C S R$ mampu memperkuat pengaruh dari profitabilitas terhadap nilai perusahaan. Hasil serupa ditemukan oleh Pramana dan Mustanda (2017) yaitu $C S R$ mampu memoderasi pengaruh profitabilitas terhadap nilai perusahaan dimana sifat moderasinya adalah positif (memperkuat pengaruh positifnya). Hipotesis yang diajukan dalam penelitian ini adalah sebagai berikut :

$\mathrm{H}_{3}$ : Pengungkapan $C S R$ memperkuat pengaruh profitabilitas terhadap nilai perusahaan. 
Leverage merupakan tingkat kemampuan perusahaan untuk memenuhi kewajiban finansialnya baik dalam jangka pendek maupun dalam jangka panjang, atau mengukur seberapa jauh operasi perusahaan dibiayai oleh hutang. Menurut Riyanto (1997) dalam Bernandhi (2013) menyatakan bahwa leverage adalah penggunaan dana atau aset di mana perusahaan harus menutup biaya tetap atau membayar beban tetap untuk penggunaan dana atau aset tersebut. Leverage tidak lain adalah sumber dana eksternal sebab kedudukan leverage mewakili hutang yang dimiliki perusahaan. Apabila perusahaan dapat mengelola hutang dengan baik guna meningkatkan keuntungan maka akan memberikan respon positif bagi investor.

Menurut Kokubu et al. (2001) dalam Sembiring (2005) yang menyatakan bahwa meskipun tingkat hutang yang dimiliki oleh perusahaan tersebut tinggi, tetapi terdapat hubungan yang baik antara perusahaan dan debtholders serta mampu memberikan informasi tanggung jawab sosial perusahaan yang baik maka perusahaan tersebut diduga mampu meningkatkan nilai perusahaan walaupun mempunyai suatu derajat ketergantungan yang tinggi pada hutang. Pengungkapan tanggung jawab sosial perusahaan dilakukan untuk mendapatkan nilai positif dan legitimasi dari masyarakat. Bagi perusahaan legitimasi dianggap penting karena legitimasi masyarakat kepada perusahaan menjadi faktor strategis bagi perkembangan serta peningkatan nilai perusahaan ke depan dan memiliki manfaat untuk mendukung keberlangsungan hidup suatu perusahaan (going concern).

Berdasarkan penelitian terdahulu yang dilakukan oleh Wulandari dan Wiksuana (2017) serta Jayanti dan Suputra (2015) menunjukkan hasil bahwa CSR 
Ni Made Laksmi Dewi dan I D.G. Dharma Suputra. Pengaruh ...

dapat memoderasi pengaruh leverage terhadap nilai perusahaan. Hipotesis yang diajukan dalam penelitian ini adalah sebagai berikut:

$\mathrm{H}_{4}$ : Pengungkapan $C S R$ memperlemah pengaruh leverage terhadap nilai perusahaan.

\section{METODE PENELITIAN}

Penelitian ini dilakukan pada perusahaan yang tergabung dalam perusahaan pertambangan di Indonesia yang terdaftar di Bursa Efek Indonesia melalui situs resminya yaitu www.idx.co.id. Objek penelitian ini adalah nilai perusahaan, profitabilitas, leverage, dan Corporate Social Responsibility pada perusahaan pertambangan yang terdaftar di Bursa Efek Indonesia (BEI) pada periode 20152017.

Variabel bebas penelitian ini adalah profitabilitas dan leverage. Variabel terikat dalam penelitian ini adalah nilai perusahaan. Variabel moderasi dalam penelitian ini adalah Corporate Social Responsibility (CSR).

Rumus Tobin's Q adalah sebagai berikut (Saraswati dan Hadiprajitno, 2012):

Tobin's $Q=\frac{\mathrm{MVE}+\mathrm{DEBT}}{\mathrm{TA}}$

Keterangan :

MVE : harga penutupan saham pada akhir tahun buku dikalikan dengan jumlah saham beredar

DEBT : total hutang perusahaan

$T A \quad$ : nilai total aset dalam laporan kuangan 
Pada penelitian ini perhitungan Return On Assets (ROA) menurut Brigham dan Houston (2010), dan Kasmir (2014:202) sebagai berikut:

$\mathrm{ROA}=\frac{\text { Laba bersih setelah pajak }}{\text { Total aset }} \times 100 \%$

Rumus untuk menghitung DER sebagai berikut (Husnan dan Pudjiastuti, $2004: 70)$ :

DER $=\frac{\text { Total Hutang }}{\text { Total Ekuitas }} \times 100 \%$

Metode pengukuran $C S R$ berdasarkan pengukuran yang telah dilakukan oleh penelitian sebelumnya sebagai berikut (Dewi dan Wirawati, 2018) :

$\mathrm{CSRDI}_{\mathrm{J}}=\frac{\sum x i j}{\mathrm{nj}}$

Keterangan :

CSRDIj : Corporate Sosial ResponsibilityDisclosure Index perusahaan j

Xij $\quad$ : variabel dummy: $1=$ jika item I diungkapkan; $0=$ jika item I tidak diungkapkan

$\mathrm{Nj} \quad$ : jumlah item untuk perusahaan $\mathrm{j}, \mathrm{nj} \leq 91$

Populasi dalam penelitian ini adalah perusahaan pertambangan yang terdaftar di Bursa Efek Indonesia pada periode 2015-2017 yaitu sebanyak 41 perusahaan. Sampel dalam penelitian ini adalah perusahaan pertambangan yang terdaftar di BEI tahun 2015-2017, yang dipilih menggunakan metode non probability sampling dengan teknik purposive sampling. Sampel perusahaan tersebut dipilih berdasarkan kriteria-kriteria seperti yang ditunjukkan oleh Tabel 1 berikut. 
Tabel 1.

Penentuan Sampel Penelitian

\begin{tabular}{|c|c|}
\hline Kriteria & Jumlah \\
\hline $\begin{array}{l}\text { Perusahaan pertambangan yang terdaftar di BEI } \\
\text { pada tahun } 2015-2017\end{array}$ & 41 \\
\hline $\begin{array}{l}\text { Tidak menemukan pengungkapan } C S R \text { dalam } \\
\text { laporan tahunan ataupun laporan berkelanjutan } \\
\text { perusahaan pertambangan }\end{array}$ & (27) \\
\hline $\begin{array}{l}\text { Jumlah perusahaan yang digunakan sebagai } \\
\text { sampel }\end{array}$ & 14 \\
\hline $\begin{array}{l}\text { Jumlah data observasi ( } 14 \text { perusahaan x } 3 \text { tahun } \\
\text { pengamatan) }\end{array}$ & 42 \\
\hline
\end{tabular}

Teknik analisis data yang digunakan dalam penelitian ini adalah Moderated Regression Analysis(MRA). Persamaan MRA dalam penelitian ini adalah sebagai berikut :

$Y=\alpha+\beta_{1} X_{1}+\beta_{2} X_{2}+\beta_{3} Z+\beta_{4} X_{1} Z+\beta_{5} X_{2} Z+e$

Keterangan :

$\mathrm{Y} \quad=$ Nilai Perusahaan

$\alpha \quad=$ Konstan

$\beta \quad=$ Koefisien Regresi

$\mathrm{X}_{1} \quad=$ Profitabilitas

$\mathrm{X}_{2} \quad=$ Leverage

$\mathrm{Z} \quad=$ Pengungkapan CSR

$\mathrm{X}_{1} \mathrm{Z}=$ Interaksi antara Profitabilitas denganCSR

$\mathrm{X}_{2} \mathrm{Z}=$ Interaksi antara Leverage dengan $C S R$

$\mathrm{e} \quad=$ Kesalahan Residual

\section{HASIL DAN PEMBAHASAN}

Statistik deskriptif memberikan informasi karakteristik variabel penelitian khususnya terkait nilai minimum, nilai maksimum, nilai rata-rata (mean) dan standar deviasi. Hasil dari analisis statistic deskriptif penelitian dapat dilihat pada Tabel 2. 
Tabel 2.

Hasil Analisis Statistik Deskriptif

\begin{tabular}{|c|c|c|c|c|c|}
\hline & $\mathrm{N}$ & Minimum & Maximum & Mean & Std. Deviation \\
\hline Profitabilitas & 42 &,- 0872 & ,6867 & , 103948 &, 1618159 \\
\hline Leverage & 42 &, 0425 & 8,7858 & 1,109110 & 1,7560609 \\
\hline CSR & 42 & ,0769 & ,9560 & ,291200 &, 1683443 \\
\hline Nilai Perusahaan & 42 & , 1047 & 17,5098 & 2,452593 & 4,3814425 \\
\hline Valid N (listwise) & 42 & & & & \\
\hline
\end{tabular}

Sumber: Data diolah, 2018

Berdasarkan hasil uji statistik deskriptif Tabel 2 diatas, didapatkan informasi bahwa variabel profitabilitas yang di proksikan dengan $R O A$ memiliki 42 sampel penelitian. Variabel profitabilitas memiliki nilai minimum sebesar 0,0872 yang berarti nilai terendah dari variabel profitabilitas yaitu dari perusahaan PT. Bayan Resources Tbk (BYAN). Nilai maksimum profitabilitas adalah sebesar 0,6867 yang berarti nilai tertinggi dari variabel profitabilitas yaitu dari perusahaan PT. Elnusa Tbk (ELSA). Mean dari profitabilitas sebesar 0,103948 artinya ratarata profitabilitas pada 42 sampel perusahaan pertambangan pada tahun 20152017 adalah 0,103948. Nilai rata-rata profitabilitas lebih mendekati nilai minimumnya, ini berarti rata-rata profitabilitas perusahaan tambang cenderung rendah. Standar deviasi sebesar 0,1618159. Nilai standar deviasi yang lebih besar dari nilai rata-rata artinya terdapat fluktuasi yang cukup tinggi pada profitabilitas di perusahaan yang menjadi sampel.

Variabel leverage yang diproksikan dengan DER memiliki 42 sampel penelitian. Variabel Leverage memiliki nilai minimum sebesar 0,0425 yang berarti nilai terendah dari variabel leverage yaitu perusahaan PT. Central Mega Resources Tbk (DKFT). Nilai maksimum leverage adalah sebesar 8,7858 yang berarti nilai tertinggi variabel leverage yaitu dari perusahaan PT. Delta Dunia Tbk (DOID). Mean dari leverage sebesar 1,109110 artinya rata-rata leverage pada 42 
Ni Made Laksmi Dewi dan I D.G. Dharma Suputra. Pengaruh ...

sampel perusahaan pertambangan pada tahun 2015-2017 adalah sebesar 1,109110. Nilai rata-rata leverage lebih mendekati nilai minimumnya, ini berarti rata-rata leverage perusahaan tambang cenderung rendah. Standar deviasi sebesar 1,7560609. Nilai standar deviasi yang lebih besar dari nilai rata-rata artinya terdapat fluktuasi yang cukup tinggi pada leverage di perusahaan yang menjadi sampel.

Variabel corporate social responsibility yang diproksikan dengan CSRDI memiliki 42 sampel penelitian. Variabel CSR memiliki nilai minimum 0,0769yang berarti nilai terendah dari variabel $C S R$ yaitu perusahaan PT. Central Mega Resources Tbk (DKFT). Nilai maksimum CSR adalah sebesar 0,9560 yang berarti nilai tertinggi dari variabel CSR yaitu dari perusahaan PT. Bukit Asam Tbk (PTBA). Mean dari CSR adalah 0,291200 artinya rata-rata $C S R$ pada 42 sampel perusahaan pertambangan pada tahun 2015-2017 adalah sebesar 0,291200. Nilai rata-rata $C S R$ lebih mendekati nilai minimumnya, ini berarti rata-rata $C S R$ perusahaan tambang cenderung rendah. Standar deviasi sebesar 0,1683443 . Nilai standar deviasi yang lebih kecil dari nilai rata-rata artinya terdapat fluktuasi yang rendah pada leverage di perusahaan yang menjadi sampel.

Variabel nilai perusahaan yang di proksikan dengan Tobin's $Q$ memiliki 42 sampel penelitian. Variabel nilai perusahaan memiliki nilai minimum sebesar 0,1047 yang berarti nilai terendah dari variabel nilai perusahaan yaitu dari perusahaan PT. Harum Energy Tbk (HRUM). Nilai maksimum nilai perusahaan adalah sebesar 17,5098 yang berarti nilai tertinggi dari variabel nilai perusahaan yaitu dari perusahaan PT. Indo Tambangraya Megah Tbk (ITMG). Mean dari nilai 
perusahaan sebesar 2,452593 artinya rata-rata nilai perusahaan pada 42 sampel perusahaan pertambangan pada tahun $2015-2017$ adalah 2,452593. Nilai rata-rata variabel nilai perusahaan lebih mendekati nilai minimumnya, ini berarti rata-rata nilai perusahaan pada perusahaan tambang cenderung rendah. Standar deviasi sebesar 4,3814425. Nilai standar deviasi yang lebih besar dari nilai rata-rata artinya terdapat fluktuasi yang cukup tinggi pada nilai perusahaan di perusahaan yang menjadi sampel.

Pengujian data dalam penelitian ini menggunakan teknik analisis regresi moderasi. Hasil pengujian disajikan pada Tabel 3. berikut:

Tabel 3.

Hasil Analisis Regresi Moderasi

\begin{tabular}{|c|c|c|c|c|c|}
\hline \multirow[t]{2}{*}{ Model } & \multicolumn{2}{|c|}{$\begin{array}{l}\text { Unstandardized } \\
\text { Coefficients }\end{array}$} & \multirow{2}{*}{$\begin{array}{c}\text { Standardized } \\
\text { Coefficients } \\
\text { Beta }\end{array}$} & \multirow[b]{2}{*}{$\mathrm{t}$} & \multirow[b]{2}{*}{ Sig. } \\
\hline & $\mathrm{B}$ & Std. Error & & & \\
\hline $\begin{array}{ll}1 & \text { (Constant) }\end{array}$ & .007 & .092 & & .073 & .942 \\
\hline Profitabilitas & .386 & .101 & .468 & 3.812 & .001 \\
\hline Leverage & -.040 & .053 & -.093 & -.756 & .454 \\
\hline CSR & .091 & .096 & .110 & .953 & .347 \\
\hline Interaksi X1.Z & .203 & .085 & .264 & 2.391 & .022 \\
\hline Interaksi X2.Z & .304 & .126 & .323 & 2.424 & .020 \\
\hline R Square & & & & & 0,629 \\
\hline Adjusted R Square & & & & & 0,577 \\
\hline F Statistik & & & & & 12,188 \\
\hline Signifikansi & & & & & 0,000 \\
\hline
\end{tabular}

Berdasarkan hasil analisis seperti yang disajikan pada Tabel 3, maka persamaan strukturalnya adalah sebagai berikut :

$$
Y=0,386 X_{1}-0,040 X_{2}+0,091 X_{3}+0,203 X_{1} \cdot Z+0,304 X_{2} \cdot Z+\varepsilon
$$

Koefisien determinasi $\left(\mathrm{R}^{2}\right)$ digunakan untuk mengetahui dan mengukur kemampuan model dalam menerangkan variasi variabel independen. Peneliti menggunakan nilai adjusted $\mathrm{R}^{2}$ pada saat mengevaluasi yang mana model regresi terbaik, karena tidak seperti $\mathrm{R}^{2}$, nilai adjusted $\mathrm{R}^{2}$ dapat naik atau turun apabila 
Ni Made Laksmi Dewi dan I D.G. Dharma Suputra. Pengaruh ...

satu variabel independen ditambahkan ke dalam model. Hasil uji memberikan hasil dimana diperoleh besarnya adjusted $\mathrm{R}^{2}$ (koefisien determinasi yang telah disesuaikan) pada Tabel 3 adalah 0,577. Ini berarti variasi nilai perusahaan dapat dipengaruhi secara signifikan oleh variabel profitabilitas $\left(\mathrm{X}_{1}\right)$, leverage $\left(\mathrm{X}_{2}\right), \mathrm{CSR}$ (Z), interaksi $X_{1} \cdot Z$ dan interaksi $X_{2} \cdot Z$ sebesar 57,7 persen, sedangkan sisanya sebesar 42,3 persen dijelaskan oleh faktor-faktor lain yang tidak dijelaskan dalam model penelitian.

Uji keterandalan model atau uji kelayakan model atau yang lebih populer disebut sebagai uji $\mathrm{F}$ merupakan tahapan awal mengidentifikasi model regresi yang diestimasi layak atau tidak. Layak (andal) disini maksudnya adalah model yang diestimasi layak digunakan untuk menjelaskan pengaruh variabel-variabel bebas terhadap variabel terikat.Sig.Tabel ANOVA menunjukkan besarnya angka probabilitas atau signifikansi pada perhitungan ANOVA. Nilai yang tertera digunakan untuk uji kelayanan Model Analisis (dimana sejumlah variabel $\mathrm{x}$ mempengaruhi variabel y) dengan ketentuan angka probabilitas yang baik untuk digunakan sebagai model regresi harus $<0,05$. Nilai ini bisa dilihat pada kolom Sig. Jika signifikansi $<0,05$, maka Model Analisis dianggap layak. Jika nilai signifikansi > 0,05, maka Model Analisis dianggap tidak layak. Hasil uji F dalam penelitian ini dapat dilihat pada Tabel 4 .

Tabel 4.

Hasil Uji F

\begin{tabular}{llrrrrr}
\hline Model & & Sum of Squares & df & Mean Square & F & Sig. \\
\hline 1 & Regression & 17.351 & 5 & 3.470 & 12.188 & $.000^{\mathrm{a}}$ \\
& Residual & 10.250 & 36 & .285 & & \\
& Total & 27.601 & 41 & & & \\
\hline
\end{tabular}

Sumber: Data diolah, 2018 
Hasil uji F (Ftest) pada Tabel 4 menunjukkan bahwa nilai signifikansi $\mathrm{P}$ value 0,000 yang lebih kecil dari $\alpha=0,05$, ini berarti model yang digunakan pada penelitian ini adalah layak. Hasil ini memberikan makna bahwa seluruh variabel independen mampu memprediksi atau menjelaskan fenomena nilai perusahaan. Dengan kata lain profitabilitas $\left(\mathrm{X}_{1}\right)$, leverage $\left(\mathrm{X}_{2}\right), \operatorname{CSR}(\mathrm{Z})$, interaksi profitabilitas dengan CSR dan interaksi leverage dengan CSR secara simultan berpengaruh signifikan terhadap nilai perusahaan. Hal ini berarti model dapat digunakan untuk analisa lebih lanjut atau dengan kata lain model dapat digunakan untuk memproyeksikan karena hasil goodness of fitnya baik dengan nilai signifikansi $\mathrm{P}$ value 0,000 .

Variabel moderasi dapat diklasifikasikan menjadi 4 jenis. Masing-masing klasifikasi moderasi dapat diidentifikasi sebagaimana contoh berikut, jika X adalah variabel predictor, $\mathrm{Y}$ variabel terikat dan $\mathrm{M}$ variabel moderasi maka persamaan regresi yang dapat dibentuk sebagai berikut :

$$
\mathrm{Y}=\beta_{1} \mathrm{X}_{1}+\beta_{2} \mathrm{M}_{1}+\beta_{3} \mathrm{X}_{1} * \mathrm{M}_{1}
$$

Tabel 5.

Klasifikasi Variabel Moderasi

\begin{tabular}{cll}
\hline No. & \multicolumn{1}{c}{ Tipe Moderasi } & \multicolumn{1}{c}{ Koefisien } \\
\hline 1. & Pure Moderasi & $\mathrm{b}_{2}$ non significant \\
& & $\mathrm{b}_{3}$ significant \\
2. & Quasi Moderasi & $\mathrm{b}_{2}$ significant \\
& & $\mathrm{b}_{3}$ significant \\
3. & Homologiser Moderasi & $\mathrm{b}_{2}$ non significant \\
& & $\mathrm{b}_{3}$ nonsignificant \\
4. & Predictor Moderasi & $\mathrm{b}_{2}$ significant \\
& & $\mathrm{b}_{3}$ nonsignificant \\
\hline Sumber: Solimun, 2010 &
\end{tabular}

Pada Tabel 3 Hasil Uji Regresi Moderasi menunjukkan bahwa variabel CSR memiliki nilai signifikansi sebesar $0,337>0,050$ maka $b_{2}$ non significant. Variabel interaksi X1.Z dan X2.Z menunjukkan nilai signifikansi masing-masing 
Ni Made Laksmi Dewi dan I D.G. Dharma Suputra. Pengaruh ...

0,022 dan 0,020 lebih kecil dari nilai signifikansi 0,050 maka $b_{3}$ significant. Hasil penelitian menunjukkan bahwa tipe moderasi pada penelitianini adalah termasuk tipe pure moderasi.

Hipotesis pertama penelitian ini menyatakan bahwa profitabilitas berpengaruh positif terhadap nilai perusahaan. Hasil penelitian diperoleh nilai koefisien regresi untuk variabel profitabilitas sebesar 0,386 dengan nilai signifikansi sebesar 0,001 dimana lebih kecil dari 0,05. Hasil ini menunjukkan bahwa profitabilitas berpengaruh positif dan signifikan pada nilai perusahaan pertambangan di Bursa Efek Indonesia tahun 2015-2017, sehingga hipotesis pertama dapat diterima. Hasil penelitian tersebut menunjukkan bahwa profitabilitas yang di proksikan dengan ROA mampu mempengaruhi keadaan perusahaan yang berdampak pada nilai perusahaan.

Teori sinyal menjelaskan bagaimana sebuah perusahaan mengeluarkan sinyal berupa informasi yang menjelaskan keadaan perusahaan tersebut. Nilai ROA yang tinggi merupakan sinyal positif bagi investor bahwa perusahaan dalam kondisi yang menguntungkan. Profitabilitas yang tinggi mencerminkan kemampuan perusahaan dalam menghasilkan keuntungan yang tinggi bagi pemegang saham, sehingga dapat menarik minat investor untuk menanamkan modalnya di perusahaan tersebut, hal ini pada akhirnya akan dapat meningkatkan nilai perusahaan. Hasil penelitian ini didukung oleh penelitian yang dilakukan oleh Dewi dan Mertha (2018) yang menunjukkan bahwa profitabilitas berpengaruh positif dan signifikan terhadap nilai perusahaan. 
Hipotesis kedua penelitian ini menyatakan bahwa leverage berpengaruh negatif terhadap nilai perusahaan. Hasil penelitian diperoleh nilai koefisien regresi untuk variabel leverage sebesar -0,040 dengan nilai signifikansi sebesar 0,454 dimana lebih besar dari 0,05. Hasil ini menunjukkan bahwa leverage berpengaruh negatif dan tidak signifikan pada nilai perusahaan pertambangan yang terdaftar di Bursa Efek Indonesia pada tahun 2015-2017, sehingga hipotesis kedua ditolak.

Dalam teori sinyal perusahaan yang memberikan berita baik akan direspon positif oleh pasar, sedangkan perusahaan yang tidak memberikan berita baik yang kinerja keuangan masa lalunya tidak bagus akan direspon negatif oleh pasar atau tidak dipercaya oleh pasar. Perusahaan dalam mendanai aktivanya cenderung menggunakan modal sendiri (internal financing) yang berasal dari laba ditahan dan modal saham daripada menggunakan hutang. Kecukupan dana yang dimiliki perusahaan mengurangi proporsi hutangnya. Penggunaan hutang yang berlebihan akan mengurangi manfaat yang diterima atas penggunaan hutang karena manfaat yang diterima tidak sebanding dengan biaya yang ditimbulkan, sehingga hutang yang rendah dapat meningkatkan nilai perusahaan dan sebaliknya peningkatan hutang dapat menurunkan nilai perusahaan. Seberapapun banyaknya penggunaan hutang tidak akan berpengaruh terhadap harga saham dan nilai perusahaan karena penggunaan hutang tidak akan menyebabkan biaya ekuitas biasa naik dengan tingkat yang sama. Hasil penelitian ini didukung oleh penelitian yang dilakukan Novari dan Lestari (2016), serta Nuraeni (2016) yang menunjukkan bahwa leverage berpengaruh negatif dan tidak signifikan terhadap nilai perusahaan. 
Ni Made Laksmi Dewi dan I D.G. Dharma Suputra. Pengaruh ...

Hipotesis ketiga penelitian ini menyatakan bahwa CSR memperkuat pengaruh profitabilitas terhadap nilai perusahaan. Hasil penelitian diperoleh nilai koefisien regresi untuk variabel interaksi $X_{1} . Z$ sebesar 0,203 dengan nilai signifikansi sebesar 0,022 dimana lebih kecil dari 0,05. Sementara untuk koefisien regresi untuk variabel profitabilitas sebesar 0,386 dengan nilai signifikansi sebesar 0,001 dimana lebih kecil dari 0,05. Maka hal tersebut menunjukkan adanya hubungan searah karena sama-sama memiliki nilai koefisien yang positif, menunjukkan bahwa variabel CSR merupakan variabel moderasi yang memperkuat pengaruh profitabilitas pada nilai perusahaan.

Teori legitimasi mendorong perusahaan untuk melakukan pengungkapan sukarela sebagai salah satu bentuk pertanggungjawaban terhadap kontrak sosial yang dimiliki antara perusahaan dengan komunitas sekitarnya (Guthrie et al.,2004). Menurut Bowman dan Haire (1976) dan Preston (1978) dalam Agustine (2014), semakin tinggi tingkat profitabilitas perusahaan maka semakin besar pengungkapan informasi sosial yang dilakukan perusahaan. Masyarakat saat ini cenderung memilih perusahaan yang bertanggung jawab dan peduli terhadap lingkungan sekitar karena dengan mendukung perusahaan tersebut secara tidak langsung masyarakat pun ikut berpartisipasi dalam memelihara lingkungan sekitar (Susanti dan Santoso, 2011). Perusahaan dengan tingkat profitabilitas yang tinggi akan selalu berusaha untuk meningkatkan pengungkapan kegiatan sosial yang dilakukan oleh perusahaan sebagai usaha untuk meyakinkan investor bahwa perusahaan tidak hanya memperhatikan tujuan jangka pendek (profit), namun juga tujuan jangka panjang yaitu peningkatan nilai perusahaan (Yuniasih dan 
Wirakusuma, 2007). Hasil penelitian ini didukung oleh penelitian yang dilakukan Pramana dan Mustanda (2017) yang menunjukkan bahwa pengungkapan CSR sebagai variabel pemoderasi memperkuat pengaruh profitabilitas terhadap nilai perusahaan.

Hipotesis keempat penelitian ini menyatakan bahwa CSR memperlemah pengaruh leverage terhadap nilai perusahaan. Hasil penelitian diperoleh nilai koefisien regresi untuk variabel interaksi $\mathrm{X}_{2} . \mathrm{Z}$ sebesar 0,304 dengan nilai signifikansi sebesar 0,020 dimana lebih kecil dari 0,05. Sementara untuk koefisien regresi untuk variabel leverage sebesar -0,040 dengan nilai signifikansi sebesar 0,454 dimana lebih besar dari 0,05. Artinya ada hubungan yang tidak searah atau berlawanan karena memiliki nilai koefisien yang berbeda. Hal ini menunjukkan bahwa variabel CSR merupakan variabel moderasi yang memperlemah pengaruh leverage pada nilai perusahaan.

Perusahaan dengan tingkat leverage yang tinggi akan cenderung mengurangi pengungkapan tanggung jawab sosialnya agar tidak menjadi sorotan dari pihak debtholder yang akan berdampak pada nilai perusahaan. Leverage merupakan suatu kebijakan yang dilakukan oleh suatu perusahaan dalam menginvestasi dana atau memperoleh sumber dana yang disertai dengan adanya beban atau biaya tetap yang harus ditanggung perusahaan. Semakin tinggi tingkat leverage maka semakin besar perusahaan akan melanggar perjanjian kredit sehingga perusahaan akan berupaya untuk melaporkan laba sekarang lebih tinggi dibandingkan laba dimasa depan (Belkaoui dan Karpik, 1989 dalam Anugerah, dkk, 2010). Laba yang dilaporkan tinggi akan membuat manajer harus 
Ni Made Laksmi Dewi dan I D.G. Dharma Suputra. Pengaruh ...

mengurangi biaya atau pengeluaran, termasuk biaya atau pengeluaran untuk mengungkapkan tanggung jawab sosial (Anugerah, et al, 2010). Menurut Friedman (1970) dalam Chang (2014) menyatakan bahwa penggunaan hutang yang tinggi dengan diimbangi dengan pelaksanaan $C S R$ yang tinggi mampu mengurangi daya saing perusahaan sehingga berdampak pada penurunan nilai perusahaan. Hasil penelitian ini didukung oleh penelitian yang dilakukan Wulandari dan Wiksuana (2017) serta Jayanti dan Suputra (2015) yang menunjukkan bahwa pengungkapan CSR sebagai variabel pemoderasi memperlemah pengaruh leverage terhadap nilai perusahaan.

\section{SIMPULAN}

Profitabilitas yang diproksikan menggunakan $R O A$ berpengaruh secara positif dan signifikan pada nilai perusahaan. Hal tersebut menjelaskan bahwa jika terjadi peningkatan profitabilitas, maka nilai perusahaan juga akan mengalami peningkatkan.

Leverage yang diproksikan menggunakan $D E R$ berpengaruh secara negatif dan tidak signifikan pada nilai perusahaan. Hal tersebut menjelaskan bahwa besar kecilnya hutang yang dimiliki perusahaan tidak terlalu diperhatikan oleh investor.

Pengungkapan corporate social responsibility memperkuat pengaruh hubungan profitabilitas pada nilai perusahaan. Hal tersebut berarti bahwa jika terjadi peningkatan pengungkapan tanggung jawab sosial, maka akan memperkuat pengaruh profitabilitas pada nilai perusahaan. 
Pengungkapan corporate social responsibility memperlemah pengaruh leverage pada nilai perusahaan. Hal tersebut berarti bahwa jika terjadi peningkatan pengungkapan corporate social responsibility, maka akan memperlemah pengaruh leverage pada nilai perusahaan.

Bagi perusahaan pertambangan di Indonesia diharapkan untuk lebih meningkatkan dan bersungguh-sungguh dalam menerapkan Corporate Social Responsibility. Corporate Social Responsibility bukan hanya sebuah pertanggungjawaban perusahaan kepada lingkungan dan masyarakat, namun juga bila dimaksimalkan dapat memberikan keuntungan jangka panjang kepada perusahaan.

Investor dalam mengambil keputusan dalam berinvestasi, sebaiknya tidak hanya melihat dari informasi keuangannya saja.Namun juga tetap melihat aspek non keuangan seperti penerapan Corporate Social Responsibility yang dilakukan oleh perusahaan karena apabila penerapan Corporate Social Responsibility di suatu perusahaan baik makaakan meningkatkan nilai perusahaan.

\section{REFERENSI}

Agustina, Silvia. (2012). Pengaruh Profitabilitas dan Pengungkapan Corporate Social Responsibility Terhadap Nilai Perusahaan.Skripsi.Universitas Negeri Padang.

Agustine, Ira. (2014). Pengaruh Corporate Social Responsibility Terhadap Nilai Perusahaan.FINESTA. 2(1).pp: 42-47

Bernandhi, Riza. (2013). Pengaruh Kepemilikan Manajerial, Kepemilikan Institusional, Kebijakan Dividen, Leverage, dan Ukuran Perusahaan terhadap Nilai Perusahaan. E-Jurnal Akuntansi Universitas Diponogoro.3(1). pp:2337-3806. 
Ni Made Laksmi Dewi dan I D.G. Dharma Suputra. Pengaruh ...

Brigham, Eugene F. dan J. F. Houston.(2010). Manajemen Keuangan.Edisi Kedelapan. Jakarta: Erlangga.

Chang, Yuan dan Chung-Hua Shen.(2014). Corporate Social Responsibility and Profitability-Cost of Debt as the Mediator.Taipe Economic Inquiry.50(2). pp:291-357.

Cheng, Ming-Chang, and Tzeng, Zuwei_Ching.(2011). The Effect of Leverage on irm Value and How The Firm Financial Quality Influence on This Effect. World Journal of Management 3(2).pp.30-53.

Dewi, A.A.A. Trisna Wulan dan Ni Gst. Putu Wirawati.(2018). Pengaruh Profitabilitas pada Nilai Perusahaan dengan Corporate Social Responsibility Sebagai Variabel Intervening.E-Jurnal Akuntansi Universitas Udayana. 22(2).pp:1557-1583

Dewi, Ni Kadek Dona Puspita dan Mertha, I Made.(2018). Pengungkapan Tanggung Jawab Sosial Memoderasi Pengaruh Profitabilitas dan Ukuran Perusahaan pada Nilai Perusahaan.Jurnal Akuntansi Unud.22(3).pp:21482176.

Georgeta dan Florinita.(2013). A Study of the Relasionship between Corporate Social responsibility - Financial Performance - Firm Size. The Bucharest University of Economic studies, h:62-67.

Gray, R., Owen, D., and Adams, C. (1996).Accounting and Accountability: Changes and Challenges in Corporate Social and Environmental Reporting. Prentice Hall Europe, Hemel Hempstead.

Guthrie, J., Petty, R., and Yongvanich, K. (2004), "Using content analysis as a research method to inquire into intellectual capital reporting".Journal of Intellectual Capital, 5(2), pp:282-293.

Haruman, Tendi. (2008). Pengaruh Struktur Kepemilikan Terhadap Keputusan Keuangan dan Nilai Perusahaan.Symposium Nasional Akuntansi XI. Pontianak.

Husnan, Suad dan Enny Pudjiastuti.(2004). Dasar-dasar Manajemen Keuangan.Yogyakarta: UPP AMP YKPN.

Jayanti, A.A. Sagung Putri dan I D.G. Dharma Suputra.(2015). Kemampuan Corporate Social Responsibility (CSR) Memoderasi Pengaruh Good Corporate Governance (GCG) dan Leverage Pada Nilai Perusahaan.EJurnal Akuntansi Universitas Udayana.14(1). pp: 118-143. 
Kasmir.(2012). Analisis Laporan Keuangan.Jakarta: Rajawali Pers.

Kasmir.(2014).Analisis Laporan Keuangan. Edisi Satu. Cetakan Ketujuh. Jakarta : PT Raja Grafindo Persada.

Kurniasari, W. dan Y. Warastuti.(2015). The Relationship Between CSR and Profitability to Firm Value in Sri-Kehati Index. Journal of Economic Behavios, 5(1), h:3-14.

Lin, Chin-Shien, Ruei-Yuan Chang dan Van Dang.(2015). An Integrated Model to Explain How Corporate Social Responsibility Affects Corporate Financial Performance. Sustainability, 7(7), h:8292-8311.

Lu, Yu-Hsini, Chih-Fong Tsai \& David C.Yen.(2010). An Empirical Study of the Impact of Internet Financial Reporting on Stock Princes. International Journal of Digital Accounting research, 10(10), h:55-85.

Malino, M.R.Y.Daeng dan Wirawati,Ni Gusti Putu. (2017). Pengaruh Profitabilitas dan Kepemilikan Manajerial Pada Nilai Perusahaan dengan Pengungkapan CSR Sebagai Variabel Pemoderasi.Jurnal Akuntansi Unud. 21(3).pp2302-8556

Mardiyati, U., Ahmad, G.N., dan Putri, R. (2012). Pengaruh Kebijakan Dividen, Kebijakan Hutang dan Profitabilitas Terhadap Nilai Perusahaan Yang Terdaftar Di Bursa efek Indonesia (BEI) Periode 2005-2010. Jurnal Riset Manajemen Sains Indonesia (JRMSI), 3(1). H:1-17

Naceur, Samy Ben, and Goaied, Mohamed. (2002). The Relationship Between Dividend Policy, Financial Structure, Profitability and Firm Value. Applied Financial Economics. 12: 843-849

Nawaiseh, M.E.,S.S.Alsoboa,R.A.Y.El-Shohnah. (2015). Influence of Firm Size and Profitability on Corporate Social responsibility Disclosure by Banking Firms (CSRD): Evidence from Jordan. Journal of Applied Finance \&Banking.5(1),h:97-111.

Nila, Luh dan I Ketut Suryanawa.(2018). Pengaruh Profitabilitas dan Ukuran Perusahaan Terhadap Nilai Perusahaan Dengan Pengungkapan Corporate Social Responsibility Sebagai Pemoderasi.E-Jurnal Akuntansi Universitas Udayana.23(3). pp: 2145-2174.

Novari, Putu Mikhy dan Lestari, Putu Vivi.(2016). Pengaruh Ukuran Perusahaan, Leverage, dan Profitabilitas terhadap Nilai Perusahaan pada Sektor Properti dan Real Estate.E-Jurnal Manajemen Unud.5(9). Pp5671-5694 
Nuraeni, Elfreda Aplonia Lau dan Rina Masyithoh Haryadi.(2016). Pengaruh Leverage, Profitability, Market Value, dan Ukuran Perusahaan Terhadap Nilai Perusahaan Property yang Terdaftar di BEI Tahun 20122014.Tesis.Fakultas Ekonomi Universitas 17 Agustus 1945 Samarinda.

Pramana, Ngurang Agung Dwi dan Mustanda, Ketut.(2016). Pengaruh Profitabilitas, Size terhadap Nilai Perusahaan dengan CSR sebagai Pemoderasi.E-Jurnal Manajemen Unud.5(1).pp561-591.

Purnama Sari, Putu Indah dan Nyoman Abundanti.(2013). Pengaruh Pertumbuhan Perusahaan dan Leverage terhadap Profitabilitas dan Nilai Perusahaan.Jurnal Akuntansi, pp: 1427-1438.

Qomariah, Nurul. (2015). The Effect of Corporate Social Responsibility, Size, and Profitability Toward On the Value of Corporate. Journal of Business and Management, 17(2), h:25-30.

Raharja, KomangAdik Hari dan Dwiana, I Md. Pande.(2016). Risiko Kredit Sebagai Pemoderasi Pengaruh Leverage dan Ukuran Perusahaan Terhadap Nilai Perusahaan.E-Jurnal Akuntansi Universitas Udayana.16(1).pp645674.

Rizqia, Dwita Ayu, Siti Aisjah dan SUmiati. 2013.Effect of Managerial Ownership, Financial Leverage, Profitability, Firm Size, and Investment Opportunity on Dividend Policy and Firm Value. Research Journal of Finance and Accounting.4(11). Pp:120-130.

Saraswati, R. dan Hadiprajitno, B. (2012).Pengaruh Corporate Governance Pada Hubungan Corporate Social Responsibility dan Nilai Perusahaan Manufaktur yang Terdaftar di BEI.Jurnal Akuntansidan Auditing.9(1).h:112.

Sembiring, Eddy Rismanda. (2005). Karakteristik Perusahaan dan Pengungkapan Tanggung Jwab Sosial: Study Empiris Pada PerusahaanYang Terdaftar Di Bursa Efek Jakarta. Simposium Nasional Akuntansi VIII, Solo, 15-16 September 2005.

Solimun.(2010). Structural Equation Modelling Lisrel dan Amos. Malang: Fakultas MIPA, Universitas Brawijaya.

Susanti, Meri. dan Santoso, Eko Budi. (2011). Pengaruh Profitabilitas Terhadap Nilai Perusahaan dengan Corporate Social Responsibility Sebagai Variabel Moederasi.Kajian Akuntansi. 6(2): 124-133. 
Undang-Undang Republik Indonesia Nomor 40 Tahun 2007 tentang Perseroan Terbatas. Jakarta.

Wiagustini, Ni luh Putu. (2010). Dasar-Dasar Manajemen Keuangan. Denpasar.Udayana University Press.

Wulandari Intan, Ni Made dan I.G.B Wiksuana. (2017). Peranan Corporate Social Responsibility Dalam Memoderasi Pengaruh Profitabilitas, Leverage, Dan Ukuran Perusahaan Terhadap Nilai Perusahaan.E-Jurnal Manajemen Unud. 6(3).pp:1278-1311.

Wongso, A. (2012). Pengaruh Kebijakan Dividen, Struktur Kepemilikan, dan Kebijakan Hutang Terhadap Nilai Perusahaan dalam Perspektif Teori Agensi dan Teori Signaling. Jurnal Universitas Katolik Widya Mandala Surabaya, 1(5).h:1-6.

Yuniasih, Ni Wayan dan Mae Gede Wirakusuma.(2007). Pengaruh Kinerja keuangan Terhadap Nilai Perusahaan dengan Pengungkapan Corporate Social responsibility dan Good Corporate Governance Sebagai Variabel Pemoderasi.E-Jurnal Akuntansi Universitas Udayana.4(1). pp:2303-1018. 